\title{
PENGARUH HARGA, PROMOSI, DAN ULASAN PRODUK TERHADAP KEPUTUSAN PEMBELIAN MELALUI APLIKASI SHOPEE
}

\author{
Abdul Ghofur Ainun Najib ${ }^{1}$, Ana Noor Andriana ${ }^{2}$ \\ ${ }^{1}$ Fakultas Ilmu Sosial dan Ilmu Politik, Universitas Mulawarman, Samarinda. \\ ${ }^{2}$ Dosen Fakultas Ilmu Sosial dan Ilmu Politik, Universitas Mulawarman. \\ Email: aga.najib98@email.com,noorandriana@fisip.unmul.ac.id
}

\begin{abstract}
Abstrak
Lima quartal terakhir Shopee berada di puncak kepopuleran dengan rata-rata pengunjung web tertinggi yaitu sebesar 103.645.340 terhitung dari Q1 2020- Q1 2021, namun pada titik Q1 2021 mengalami penurunan 1.920 .800 yang berdampak tergesernya Shopee ke ranking dua setelah Tokopedia. Tujuan dari penelitian ini untuk menguji pengaruh harga, promosi, dan ulasan produk terhadap keputusan pembelian melalui aplikasi Shopee. Statistik SPSS versi 24 merupakan software yang digunakan untuk bantuan menganalisis data yaitu regresi linear berganda. Jenis penelitian yang digunakan dalam penelitian ini ialah jenis penelitian kuantitatif asosistif yang memiliki tujuan untuk mengetahui pengaruh antara dua atau lebih variabel. Pengambilan sampel pada penelitian ini menggunakan teknik purposive sampling dengan jumlah sampel sebanyak 81 responden. Teknik pengumpulan data menggunakan kepustakaan, observasi, wawancara, kuesioner dan dokumentasi. Hipotesis penelitian ini ialah adanya pengaruh harga, promosi, dan ulasan produk terhadap keputusan pembelian melalui aplikasi Shopee Pada LDK Fisip Universitas Mulawarman. Hasil analisis harga tidak berpengaruh secara parsial terhadap keputusan pembelian dengan nilai hasil uji $\mathrm{t}$ (X1) -1,511, serta promosi dan ulasan produk berpengaruh signifikan secara parsial terhadap keputusan pembelian dengan nilai hasil uji t (X2) 2,014 dan (X3) 7,095, sedangkan uji F sebesar 19,403, dengan demikian harga, promosi, dan ulasan produk berpengaruh signifikan secara simultan terhadap keputusan pembelian.
\end{abstract}

Kata Kunci: Harga; Promosi; Ulasan Produk; Keputusan Pembelian

\section{Abstract}

Shopee's last five quarters were at the peak of popularity with the highest average web visitors of 103,645,340 starting from Q1 2020-Q1 2021, but at the point of Q1 2021 there was a decline of 1,920,800 which resulted in the shifting of Shopee to rank two after Tokopedia. The purpose of this study was to examine the effect of price, promotion, and product reviews on purchasing decisions through the Shopee application. SPSS statistics version 24 is a software used to help analyze data, namely multiple linear regression. The type of research used in this research is associative quantitative research which aims to determine the effect of two or more variables. Sampling in this study using purposive sampling technique with a total sample of 81 respondents. Data collection techniques using literature, observation, 
interviews, questionnaires and documentation. The hypothesis of this research is the influence of price, promotion, and product reviews on purchasing decisions through the Shopee application at the LDK Fisip Mulawarman University. The results of price analysis have no partial effect on purchasing decisions with the value of the results of the $t$ test (X1) -1.511, and promotions and product reviews have a partially significant effect on purchasing decisions with the value of the t-test results (X2) 2.014 and (X3) 7.095, while the $F$ of 19.403, thus price, promotion, and product reviews have a significant simultaneous effect on purchasing decisions.

Keywords: Price; Promotion; Product Reviews; Buying decision

Diterima: 23-12-2021 Direvisi: 12-01-2022 Diterbitkan: 20-01-2022

\section{Pendahuluan}

Teknologi memiliki peran sangat penting dalam berbagai bidang yang dapat menunjang keefektifan dalam barbagai aktivitas manusia serta mampu mempermudah setiap keperluan hidup manusia sehari-hari. Hadirnya jaringan internet merupakan salah satu contoh kemajuan teknologi yang mana mempunyai ruang yang tidak terbatas dan jangkauannya sangat luas (Fonna, 2019). Menurut Apji yang dikenal dengan Asosiasi Penyelenggara Jasa Internet Indonesia dan Teknopreneur menyebutkan, pemakai internet yang ada di Indonesia naik sebesar 143,26 juta orang atau sama dengan 54,7 persentase atas jumlah populasi (APJII, 2018).

Saat ini cara berkomunikasi dan juga cara berbisnis telah berubah signifikan karena hadirnya jaringan internet. Fenomena tersebut menjadi salah satu sebab terhubungnya lebih banyak orang dan wirausahawan (Sudarso et al., 2020). Banyak hal baru bermunculan dari adanya perkembangan jaringan internet, pasar online merupakan salah satu hal baru yang ditimbulkan adanya fenomena tersebut. Penggunaan jaringan internet sebagai saluran pembelian yang semula cenderung untuk komunikasi pemasaran dan pencitraan kini digunakan sebagai transaksi pembelian misalnya melalui berbagai e-commerce seperti Shopee, Tokopedia, Bukalapak, lazada, Blibli dan lain sebagainya (Widagdo, 2016).

Data dari iprice.co.id pada memberikan kesimpulan bahwa Shopee merupakan ecommerce terpopuler di Indonesia karena memiliki rata-rata pengunjung web bulanan tertinggi yaitu 103.645.340 (Surahman et al., 2020).

Tabel 1. Peta E-Commerce Indonesia

\begin{tabular}{lcrrrr}
\hline Nama e-commerce & Q1 2020 & Q2 2020 & Q3 2020 & Q4 2020 & Q1 2021 \\
\hline Shopee & 71533300 & 93440300 & 96532300 & 129320800 & 127400000 \\
Tokopedia & 69800000 & 86103300 & 84997100 & 114655600 & 135076700 \\
Bukalapak & 37633300 & 35288100 & 31409200 & 38583100 & 34170000 \\
Lazada & 24400000 & 22021800 & 22674700 & 36260600 & 30516700 \\
Blibli & 17600000 & 18307500 & 18695000 & 22413100 & 19590000 \\
\hline
\end{tabular}

Sumber: https://iprice.co.id/insights/mapofecommerce/

Data tersebut diatas merupakan lima quartal terakhir yang mana Shopee berada di puncak kepopuleran dengan rata-rata pengunjung web tertinggi, namun apabila 
dianalisis lebih mendalam pada quartal satu 2021 mengalami penurunan sebesar 1.920.800 pengunjung yang berdampak tergesernya Shopee ke ranking dua setelah Tokopedia, tentu secara tidak langsung hal demikian berdampak terhadap penurunan jumlah transaksi pembelian (Febriantoro, 2018). Sehinngga dengan adanya kasus tersebut, peneliti mencoba mencari penyebab dari mengapa jumlah pengunjung Shopee mengalami penurunan melalui pengaruh harga, promosi, dan ulasan produk terhadap keputusan pembelian

\section{Metode Penelitian}

Penelitian ini menggunakan metode kuantitatif dengan jenis penelitian kuantitatif asosiatif. Penelitian kuantitatif asosiatif merupakan penelitian yang bertujuan untuk mengetahui pengaruh ataupun hubungan antara dua variabel atau lebih dengan memperoleh data yang berbentuk angka atau data statistika (P. Sugiyono, 2015).

Populasi pada penelitian ini yaitu seluruh anggota LDK Fisip Uiversitas Mulawarman yang pernah melakukan transaksi pembelian melalui aplikasi Shopee, populasi memiliki sifat heterogen yang dapat dilihat dari beragam karakteristik seperti jenis kelamin, program studi, dan usia. Sampel adalah bagian dari jumlah dan karakteristik yang dimiliki oleh populasi tersebut (Sujarweni, 2015). Sampel pada penelitian ini ialah LDK Fisip Universitas Mulawarman yang pernah melakukan transaksi pembelian melalui aplikasi Shopee dengan jumlah 81 sampel dari total 103 populasi menggunakan ketentuan rumus Slovin dengan tingkat kesalahan sebesar $5 \%$.

Teknik sampling yang digunakan dalam penelitian ini adalah Non Probability Sampling dengan jenis purposive sampling. Menurut Sugioyono purposive sampling adalah teknik pengambilan sampel sumber data dengan pertimbangan tertentu. Teknik pengumpulan data menggunakan dua jenis teknik penelitin, yaitu kepustakaan dan penelitian yang diambil secara langsung dilapangan seperti observasi, wawancara, kuesioner, serta dokumentasi (S. Sugiyono, 2015).

Alat pengukur data menggunakan Skala Likert yaitu untuk memberikan bobot nilai pada jawaban responden. Teknik analisis data merupakan cara melaksanakan analisis terhadap data, dengan tujuan mengolah data tersebut untuk menjawab rumusan masalah pada penelitian (D. Sugiyono, 2013). Sehingga pada penelitian ini menggunakan teknik analisis data dengan menggunakan metode Analisis Regresi Berganda. Uji yang digunakan sebagai berikut: 1) Uji Instrumen (Uji Validitas dan Uji Reliabilitas) 2) Uji Asumsi Klasik (Uji Normlitas, Uji Multikolinieritas, dan Uji Heterokedastisitas) 3) Analisis Regresi Linear Berganda (Koefisien Korelasi (R) dan Koefisien Determinasi $\left(\mathrm{R}^{2}\right)$ ) 4) Uji Hipotesis (Uji t Parsial dan Uji F Simultan)

\section{Hasil dan Pembahasan}

\section{Uji Instrumen}

Tabel 2. Rekapitulasi Hasil Uji Validitas

\begin{tabular}{clccc} 
Variabel & Kode Item & r-hitung & r-tabel & Keterangan \\
Penelitian & Pernyataan & & & \\
\hline
\end{tabular}




\begin{tabular}{|c|c|c|c|c|}
\hline \multirow[t]{8}{*}{ Harga (X1) } & Item01X1 & 0,543 & 0,213 & Valid \\
\hline & Item $02 X 1$ & 0,536 & 0,213 & Valid \\
\hline & Item03X1 & 0,728 & 0,213 & Valid \\
\hline & Item04X1 & 0,642 & 0,213 & Valid \\
\hline & Item05X1 & 0,620 & 0,213 & Valid \\
\hline & Item06X1 & 0,708 & 0,213 & Valid \\
\hline & Item07X1 & 0,309 & 0,213 & Valid \\
\hline & Item08X1 & 0,447 & 0,213 & Valid \\
\hline \multirow[t]{15}{*}{ Promosi (X2) } & Item09X2 & 0,332 & 0,213 & Valid \\
\hline & Item10X2 & 0,262 & 0,213 & Valid \\
\hline & Item11X2 & 0,416 & 0,213 & Valid \\
\hline & Item $12 X 2$ & 0,372 & 0,213 & Valid \\
\hline & Item13X2 & 0,391 & 0,213 & Valid \\
\hline & Item14X2 & 0,501 & 0,213 & Valid \\
\hline & Item $15 X 2$ & 0,305 & 0,213 & Valid \\
\hline & Item16X2 & 0,568 & 0,213 & Valid \\
\hline & Item17X2 & 0,603 & 0,213 & Valid \\
\hline & Item $18 X 2$ & 0,541 & 0,213 & Valid \\
\hline & Item19X2 & 0,709 & 0,213 & Valid \\
\hline & Item $20 X 2$ & 0,611 & 0,213 & Valid \\
\hline & Item $21 X 2$ & 0,591 & 0,213 & Valid \\
\hline & Item $22 X 2$ & 0,707 & 0,213 & Valid \\
\hline & Item $23 X 2$ & 0,554 & 0,213 & Valid \\
\hline \multirow{8}{*}{$\begin{array}{l}\text { Ulasan Produk } \\
\text { (X3) }\end{array}$} & Item $24 X 3$ & 0,452 & 0,213 & Valid \\
\hline & Item $25 \mathrm{X} 3$ & 0,496 & 0,213 & Valid \\
\hline & Item $26 X 3$ & 0,772 & 0,213 & Valid \\
\hline & Item $27 X 3$ & 0,696 & 0,213 & Valid \\
\hline & Item $28 X 3$ & 0,819 & 0,213 & Valid \\
\hline & Item29X3 & 0,696 & 0,213 & Valid \\
\hline & Item $30 X 3$ & 0,607 & 0,213 & Valid \\
\hline & Item $31 X 3$ & 0,606 & 0,213 & Valid \\
\hline Keputusan & Item32Y & 0,448 & 0,213 & Valid \\
\hline \multirow[t]{8}{*}{ Pembelian (Y) } & Item33Y & 0,488 & 0,213 & Valid \\
\hline & Item34Y & 0,439 & 0,213 & Valid \\
\hline & Item35Y & 0,645 & 0,213 & Valid \\
\hline & Item36Y & 0,709 & 0,213 & Valid \\
\hline & Item37Y & 0,679 & 0,213 & Valid \\
\hline & Item38Y & 0,804 & 0,213 & Valid \\
\hline & Item39Y & 0,860 & 0,213 & Valid \\
\hline & Item40Y & 0,687 & 0,213 & Valid \\
\hline
\end{tabular}

Sumber: Data diolah 2021. 
Priyatno item pernyataan dinyatakan valid sesuai dengan ketentuan uji dua sisi dengan taraf signifikan $(0,05)$ dan nilai $r$ hitung $>r$ table. Dari uji validitas pada tabel 2 tersebut semua item dinyatakan valid mengacu pada teori diatas. Sedangkan pada uji reliabilitas pada penelitian ini menggunakan skala Cronbach's Alpha, dimana konsistensi penelitian dikatakan baik apabila memiliki Cronbach's Alpha $>0,60$, Sujarweni, (2015), dimana nilai X1 adalah 0,742>0,60, untuk nilai X2 adalah 0,737> 0,60 , serta nilai X3 adalah $0,759>0,60$, dan nilai $\mathrm{Y}$ adalah $0,761>0,60$ (Priyatno, 2014).

\section{Uji Asumsi Klasik}

Pada penelitian ini, uji normalitas yang digunakan yaitu dengan metode grafik Normal P-P Plot Of Regression Standardized Residual mengacu pada teori yang mana jika titik-titik menyebar sekitar garis dan mengikuti garis diagonal, maka nilai residual tersebut telah normal (Lukito, 2017). Hasil uji normalitas dianggap berdistribusi normal mengacu pada teori tersebut dapat dilihat pada gambar dibawah sebagai berikut:

\section{Gambar 1. Grafik Normal Probability Plot}

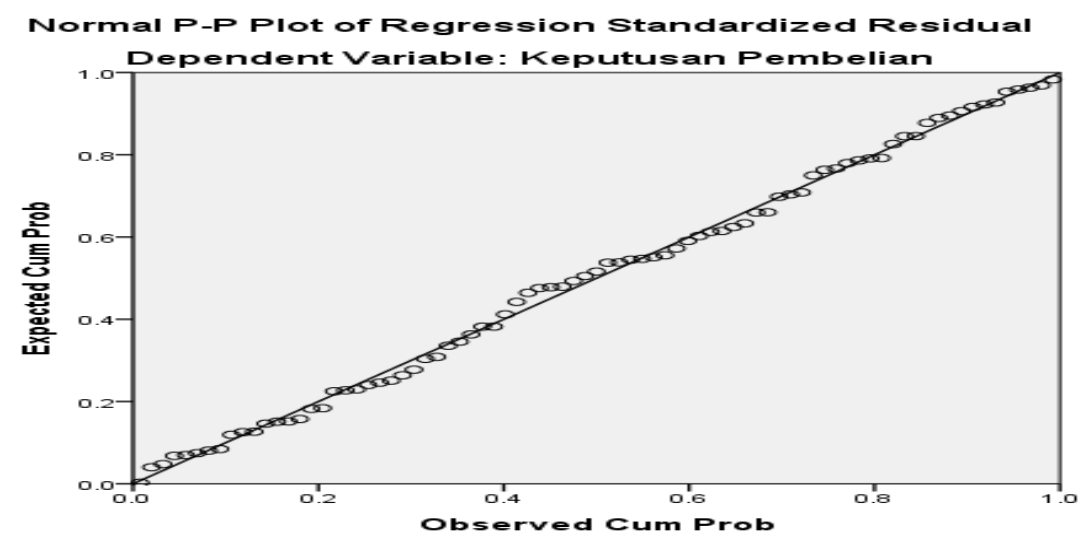

Sumber: Data diolah (2021)

Tabel 3. Hasil Uji Multikolinieritas

\section{Coefficients $^{\mathrm{a}}$}

$\begin{array}{ccc}\text { Unstandardized } & \text { Standardized } & \text { Collinearity } \\ \text { Coefficients } & \text { Coefficients } & \text { Statistics }\end{array}$

Std.

\begin{tabular}{|c|c|c|c|c|c|c|c|c|}
\hline & \multirow{2}{*}{$\frac{B}{9.082}$} & \multirow{2}{*}{$\frac{\text { Error }}{3.510}$} & \multirow[t]{2}{*}{ Beta } & \multirow{2}{*}{$\frac{\mathrm{t}}{2.588}$} & \multirow{2}{*}{$\frac{\text { Sig. }}{0.012}$} & \multirow[t]{2}{*}{ Tolerance } & \multirow[t]{2}{*}{ VIF } \\
\hline \multicolumn{2}{|c|}{$\frac{1 \text { Model }}{1 \quad \text { (Constant })}$} & & & & & & & \\
\hline \multirow{4}{*}{\multicolumn{2}{|c|}{$\begin{array}{l}\text { Harga } \\
\text { Promosi } \\
\text { Ulasan } \\
\text { Produk }\end{array}$}} & -0.167 & 0.111 & -0.142 & -1.511 & 0.135 & 0.837 & 1.194 \\
\hline & & 0.122 & 0.060 & 0.177 & 2.014 & 0.048 & 0.953 & 1.049 \\
\hline & & 0.774 & 0.109 & 0.656 & 7.095 & 0.000 & 0.865 & 1.156 \\
\hline & & & & & & & & \\
\hline
\end{tabular}




\begin{abstract}
a. Dependent Variable: Keputusan Pembelian
Sumber: Data diolah (2021)

Berdasarkan tabel diatas dapat dilihat bahwa melalui ketentuan menurut Ghozali dalam Sujarweni, (2015) dalam penelitian ini tidak terjadi multikolinearitas diantara variabel bebas karena nilai masing-masing Tolerance Value dan Variance Inflantion Factor (VIF) harga 0,837 > 0,1 dan 1,194<10,0, promosi 0,953>0,1 dan 1,049<10,0, serta ulasan produk $0,865>0,1$ dan $1,156<10,0$.

Selanjutnya pada uji heterokedastisitas dapat dilihat bahwa melalui ketentuan menurut Ghozali dalam Sujarweni, (2015) dalam penelitian ini tidak terjadi heterokedastisitas karena nilai signifikan variabel harga yaitu $0,151>0,05$, promosi $0,655>0,05$, dan ulasan produk 0,683 >0,05. Hasil uji heterokedastisitas dapat dilihat pada tebel dibawah sebagai berikut:
\end{abstract}

Tabel 4. Hasil Uji Heterokedastisitas

\title{
Coefficients $^{\mathrm{a}}$
}

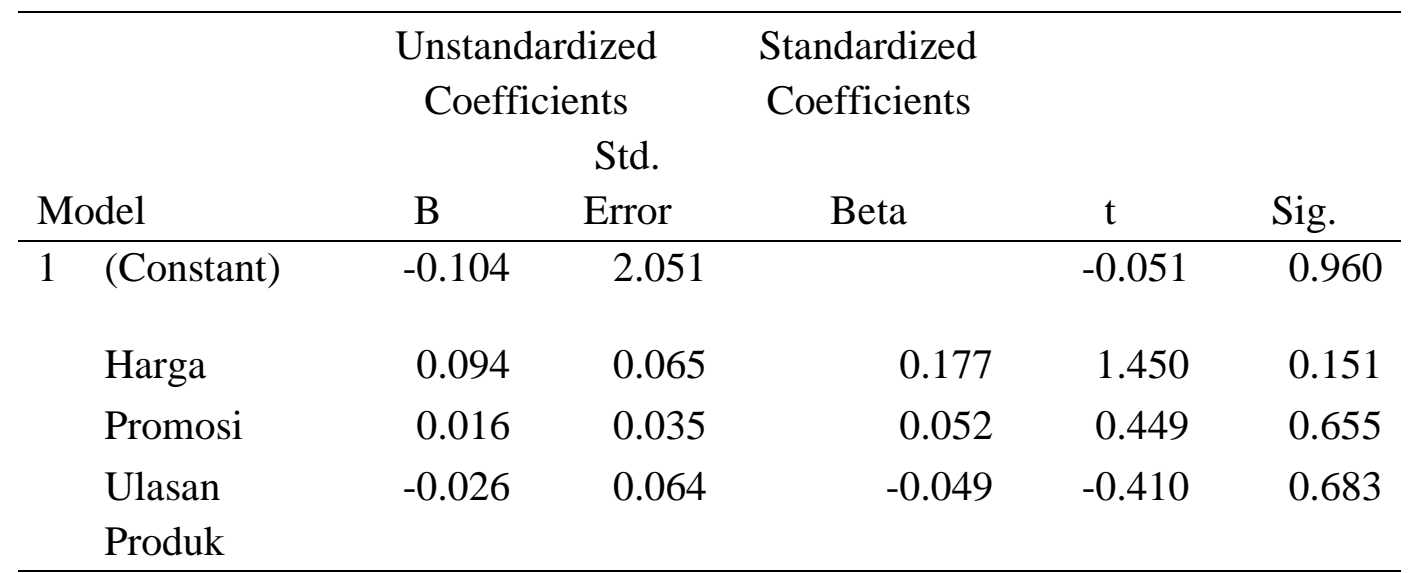

a. Dependent Variable: ABS_RES

Sumber: Data diolah (2021)

\section{Analisis Regresi Linear Berganda}

Tabel 5. Hasil Analisis Regresi Linear Berganda

Coefficients $^{\mathbf{a}}$

\begin{tabular}{|c|c|c|c|c|c|c|}
\hline \multirow{2}{*}{\multicolumn{2}{|c|}{ Model }} & \multicolumn{2}{|c|}{$\begin{array}{l}\text { Unstandardized } \\
\text { Coefficients } \\
\text { Std. }\end{array}$} & \multicolumn{3}{|l|}{$\begin{array}{l}\text { Standardized } \\
\text { Coefficients }\end{array}$} \\
\hline & & $\mathrm{B}$ & Error & Beta & $\mathrm{t}$ & Sig. \\
\hline \multirow[t]{5}{*}{1} & (Constant) & 9.082 & 3.510 & & 2.588 & 0.012 \\
\hline & Harga & -0.167 & 0.111 & -0.142 & -1.511 & 0.135 \\
\hline & Promosi & 0.122 & 0.060 & 0.177 & 2.014 & 0.048 \\
\hline & Ulasan & 0.774 & 0.109 & 0.656 & 7.095 & 0.000 \\
\hline & Produk & & & & & \\
\hline
\end{tabular}


a. Dependent Variable: Keputusan Pembelian

Sumber: Data diolah (2021)

Melihat tabel diatas diperoleh persamaan regresi linear berganda sebagai berikut:

a. Konstanta (a), Konstanta 9,082 memberitahukan bahwa variabel harga (X1), promosi (X2), dan ulasan produk (X3) tanpa mengalami perubahan atau tetap maka variabel keputusan pembelian (Y) melalui aplikasi Shopee pada LDK Fisip Universitas Mulawarman akan mengalami peningkatan sebesar 9,082.

b. Apabila terdapat penambahan satu satuan variabel harga terhadap keputusan pembelian melalui aplikasi Shopee pada LDK Fisip Universitas Mulawarman maka akan mengalami penurunan sebasar $(-0,167)$.

c. Apabila terdapat penambahan satu satuan variabel promosi terhadap keputusan pembelian melalui aplikasi Shopee pada LDK Fisip Universitas Mulawarman maka akan mengalami peningkatan sebasar 0,122 .

d. Apabila terdapat penambahan satu satuan variabel harga terhadap keputusan pembelian melalui aplikasi Shopee pada LDK Fisip Universitas Mulawarman maka akan mengalami peningkatan sebesar 0,774 .

\section{Uji Hipotesis}

Berdasarkan tabel 5. hasil analisis regresi linear berganda diperoleh hasil uji $t$ (parsial) bahwa pengaruh harga, promosi, dan ulasan produk terhadap keputusan pembelian melalui aplikasi Shopee pada LDK Fisip Universitas Mulawarman sebagai berikut:

a. Variabel harga terhadap keputusan pembelian, nilai t hitung $-1,511<1,994$ dan nilai Sig. 0,135 > 0,05, maka variabel harga tidak berpengaruh secara parsial terhadap keputusan pembelian melalui aplikasi Shopee pada LDK Fisip Universitas Mulawarman.

b. Variabel promosi terhadap keputusan pembelian, nilai t hitung 2,014 > 1,994 dan nilai Sig. 0,048 $<0,05$, maka variabel promosi berpengaruh signifikan secara parsial terhadap keputusan pembelian melalui aplikasi Shopee pada LDK Fisip Universitas Mulawarman.

c. Variabel ulasan produk terhadap keputusan pembelian, nilai t hitung 7,095 >1,994 dan nilai Sig. $0,000<0,05$, maka variabel ulasan produk berpengaruh signifikan secara parsial terhadap keputusan pembelian melalui aplikasi Shopee pada LDK Fisip Universitas Mulawarman.

Tabel 6. Hasil Uji F (Simultan)

ANOVA ${ }^{a}$

\begin{tabular}{|c|c|c|c|c|c|c|}
\hline \multicolumn{2}{|c|}{ Model } & $\begin{array}{l}\text { Sum of } \\
\text { Squares }\end{array}$ & df & Mean & $\mathrm{F}$ & \multirow{2}{*}{$\begin{array}{l}\text { Sig. } \\
.000^{\mathrm{b}}\end{array}$} \\
\hline 1 & Regression & 446.851 & 3 & 148.950 & 19.403 & \\
\hline & Residual & 591.100 & 77 & 7.677 & & \\
\hline & Total & 1037.951 & 80 & & & \\
\hline
\end{tabular}

a. Dependent Variable: Keputusan Pembelian 


\section{b. Predictors: (Constant), Ulasan Produk, Promosi, Harga}

Berdasarkan hasil perhitungan dari uji F (Simultan) diatas nilai F hitung 19,403 > F tabel 2,700 dan nilai Sig. 0,000 < 0,05, maka variabel harga, promosi, dan ulasan produk berpengaruh signifikan secara simultan terhadap keputusan pembelian melalui aplikasi Shopee pada LDK Fisip Universitas Mulawarman.

Hasil dari penelitian diatas menunjukkan bahwa harga memiliki pengaruh negatif secara parsial terhadap keputusan pembelian yang mana tidak berhubungan dan tidak berkorelasi, artinya konsumen atau responden (LDK Fisip Universitas Mulawarman) tidak terlalu mempertimbangkan harga sebagai faktor utama dalam melakukan keputusan pembelian. Hal ini didukung dengan beberapa pernyataan responden berdasarkan wawancara hasil penelitian yang mana empat dari enam responden menyatakan ulasan produk dan kualitas produk jauh lebih penting dibanding harga, tiga dari enam responden menyatakan branded, dua dari enam responden menyatakan barang primer, kemudian yang terakhir pernyataan tanpa kesamaan antara keenam responden yang telah diwawancara yaitu produk limited, domisili (hemat ongkir), toko langganan (nyaman dengan toko), barang tersier, fungsi atau manfaat, dan rating toko.

Promosi memiliki pengaruh positif secara parsial terhadap keputusan pembelian oleh sebab itu dalam meningkatkan peluang yang lebih besar terhadap keputusan pembelian melalui promosi perlu adanya berbagai macam strategi. Mengacu pada indikator tanggapan responden terhadap lima belas pernyataan promosi terdapat tiga pernyataan dengan jawaban sangat setuju dan setuju memiliki nilai akumulasi frekuensi tertinggi. Ketiga pernyataan tersebut dengan urutan nilai akumulsi tertinggi ialah sebagai berikut: a) Saya pernah melakukan pembelian karena adanya promosi diskon, dengan nilai 77 setara 95,06\%. b) Saya pernah melakukan pembelian karena adanya periklanan broadcast (wa dan sosmed lainnya), dengan nilai 65 setara 80,25\%. c) Saya pernah melakukan pembelian karena adanya periklanan di internet, dengan nilai 65 setara $80,25 \%$. Sehingga dalam meningkatkan nilai keputusan pembelian dapat berfokus pada ketiga promosi tersebut yaitu diskon, broadcast, dan periklanan di internet dengan tanpa melupakan promosi yang lainnya.

Ulasan produk memiliki pengaruh positif secara parsial terhadap keputusan pembelian serta merupakan variabel yang paling berpengaruh menurut ketentuan Sujarweni, yaitu dengan melihat nilai koefisien regresi baku, dimana nilai yang paling besar adalah variabel yang paling berpengaruh (Sujarweni, 2015). Nilai beta dari variabel ulasan produk mengacu pada tabel 5. hasil analisis regresi linear berganda adalah sebesar 0,656 sedangkan nilai beta dari variabel promosi dan harga masingmasing sebesar 0,177 dan -0,142, dengan demikian dapat disimpulkan bahwa melalui data angka yang dikuatkan dengan teori tersebut ulasan produk merupakan variabel yang paling berpengaruh terhadap keputusan pembelian melalui aplikasi shopee pada LDK Fisip Universitas Mulawarman. Oleh karena itu perlu adanya semacam strategi supaya ulasan produk yang diberikan konsumen cenderung positif sehingga dapat meningkatkan nilai keputusan pembelian, khususnya melalui foto produk yang berbanding lurus dengan kualitas produk dari aspek warna dan spesifikasi serta manfaat 
produk, kemudian yang kedua memberikan pengalaman terbaik kepada konsumen saat berbelanja melalui berbagai strategi salah satunya pelayanan yang baik, sopan, dan jujur.

Variabel independen yang terdiri dari harga, promosi, dan ulasan produk secara simultan memiliki pengaruh yang signifikan terhadap variable dependen yaitu keputusan pembelian melalui aplikasi Shopee pada LDK Fisip Universitas Mulawarman. Besar persentase antara pengaruh harga, promosi, dan ulasan produk terhadap keputusan pembelian sebesar 43,1\%. Sedangkan sisanya sebesar 56,9\% dipengaruhi oleh variabel lain yang tidak masuk pada penelitian ini.

\section{Kesimpulan}

Berdasarkan uraian dan analisis dari hasil pengujian serta pembahasan penelitian yang berjudul Pengaruh Harga, Promosi, dan Ulasan Produk Terhadap Keputusan Pembelian Melalui Aplikkasi Shopee Pada LDK Fisip Universitas Mulawarman dengan cara memberikan kuesioner kepada responden dapat diambil kesimpulan bahwa variabel harga tidak berpengaruh signifikan secara parsial terhadap keputusan pembelian melalui aplikasi shopee pada LDK Fisip Universitas Mulawarman. Selanjutnya variabel promosi dan ulasan produk berpengaruh signifikan secara parsial terhadap keputusan pembelian melalui aplikasi shopee pada LDK Fisip Universitas Mulawarman. Serta variabel harga, promosi, dan ulasan produk berpengaruh signifikan secara simultan terhadap keputusan pembelian melalui aplikasi shopee pada LDK Fisip Universitas Mulawarman. Diharapkan hasil penelitian ini dapat dikembangkan lagi dengan menambahkan variabel independen dan dependen, memperluas populasi, serta menambahkan metode analisis lainnya sehingga informasi yang diperoleh lebih akurat, baik dan bervariasi. 


\section{BIBLIOGRAFI}

APJII, B. (2018). Survei APJII: Penetrasi Internet di Indonesia Capai 143 Juta Jiwa. Apjii Available at: Https://Apjii. or. Id/Downfile/File/BULETINAPJIIEDISI22Maret2018. Pdf. Google Scholar

Febriantoro, W. (2018). Kajian dan strategi pendukung perkembangan e-commerce bagi UMKM Di Indonesia. Manajerial: Jurnal Manajemen Dan Sistem Informasi, 17(2), 184-207. Google Scholar

Fonna, N. (2019). Pengembangan Revolusi Industri 4.0 dalam Berbagai Bidang. Guepedia. Google Scholar

Lukito, I. (2017). Tantangan Hukum dan Peran Pemerintah dalam Pembangunan ECommerce. Jurnal Ilmiah Kebijakan Hukum, 11(3), 349-367. Google Scholar

Priyatno, D. (2014). SPSS 22: Practical Data Manager. Andi: Yogyakarta. Google Scholar

Sudarso, A., Purba, B., Ardiana, D. P. Y., Manullang, S. O., Karim, A., Purba, P. B., Muliana, M., Siagian, V., Siregar, M. N. H., \& Jamaludin, J. (2020). Konsep EBisnis. Yayasan Kita Menulis. Google Scholar

Sugiyono, D. (2013). Metode penelitian pendidikan pendekatan kuantitatif, kualitatif dan $R \& D$. Google Scholar

Sugiyono, P. (2015). Metode penelitian kombinasi (mixed methods). Bandung: Alfabeta, 28, 1-12. Google Scholar

Sugiyono, S. (2015). Metode penelitian kombinasi. Bandung: Alfabeta. Google Scholar

Sujarweni, V. W. (2015). Metodologi penelitian bisnis dan ekonomi. Google Scholar

Surahman, A., Octaviansyah, A. F., \& Darwis, D. (2020). Ekstraksi Data Produk EMarketplace Sebagai Strategi Pengolahan Segmentasi Pasar Menggunakan Web Crawler. Sistemasi: Jurnal Sistem Informasi, 9(1), 73-81. Google Scholar

Widagdo, P. B. (2016). Perkembangan electronic commerce (e-commerce) di Indonesia. Researchgate Article. Google Scholar

\section{First publication right:}

Jurnal Syntax Fusion: Jurnal Nasional Indonesia

This article is licensed under:

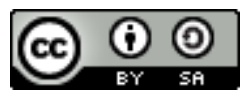

